\title{
Upper Cenozoic Volcanic Rocks in the Mariana Forearc Recovered From Drilling at Ocean Drilling Program Site 781: Implications for Forearc Magmatism
}

\author{
MiCHAEl S. MARLOW, ${ }^{1}$ LYNN E. JOHNSON, ${ }^{2}$ JULIAN A. PEARCE, ${ }^{3}$ PATRICIA B. FRYER, ${ }^{2}$ \\ LEDA BETH G. PICKTHORN, ${ }^{1}$ AND BRAMLEY J. MURTON ${ }^{4}$
}

\begin{abstract}
A horst block was drilled in the center of the Mariana forearc near $20^{\circ} \mathrm{N}$ during leg 125 of the Ocean Drilling Program. At this site 781, the drill penetrated a Pleistocene vesicular, porphyritic basalt at $72 \mathrm{~m}$ below the seafloor, and the top of the basalt corresponds to a high-amplitude reflection on seismic reflection profiles across the site. The thickness of the basalt unit can only be estimated to be between 13 and $25 \mathrm{~m}$ because of poor core recovery (28\% to 55\%). The presence of an upper glassy chilled zone and a lower, fine-grained margin suggest that the basalt unit is either a single lava flow or a near-surface sill. The basalt is an island-arc tholeite (IAT) enriched in large-ion-lithophile elements relative to high-fieldstrength elements, similar to the submarine lavas of the southern Mariana Arc seamounts. The basalt layer, the youngest in situ igneous layer reported from the Izu-Bonin and Mariana forearcs, is enigmatic because of its location more than $100 \mathrm{~km}$ from the active volcanic arc. The sediment layers above and below the basalt unit are late Pliocene (about $2.5 \mathrm{Ma}$ ) and normally magnetized. The basalt has schlierenlike structures, reverse magnetization, and a $\mathrm{K}-\mathrm{Ar}$ age of $1.68 \pm 0.37 \mathrm{Ma}$. Thus, the basalt layer is probably a sill fed by magma intruded along a fault zone bounding the horst and graben in the forearc. The geochemistry of the basalt is consistent with a magma source similar to that of rocks from the magmatic axis (or volcanic front) of the island arc, and derived from a mantle source above the subducting Pacific plate.
\end{abstract}

\section{INTRODUCTION}

Igneous rocks are not common in onshore exposures of ancient forearc assemblages that presumably formed between ancient island arcs and adjacent trenches. Hence, discoveries of igneous rocks that formed in situ in modern forearcs are important to the study of ancient forearc assemblages. One such discovery was recently documented in the Mariana forearc, in an area equidistant from the Mariana Trench and the active Mariana Island Arc. The recovery occurred during leg 125 of the Ocean Drilling Program (site 781) when a horst block was drilled in a fault zone about $13 \mathrm{~km}$ northwest of Conical Seamount, a serpentine mud volcano (Figure 1). To better understand this rare occurrence of volcanic rocks in a forearc setting, we first discuss the structural evolution of the Mariana region.

\section{Volcanic-Tectonic Setting}

Subduction of the Pacific plate beneath the Philippine Sea plate began by the middle Eocene and formed the proto Mariana arc system [Uyeda and Ben-Avraham, 1972; Karig, 1975; Hilde et al., 1977; Ogawa and Naka, 1984]. Seafloor spreading in the back arc region formed the Parece Vela Basin between about 30 and $17 \mathrm{Ma}$ and isolated the Palau-Kyushu Ridge, now a remnant arc, from its magma source (Figure 1). The West Mariana Ridge, also a remnant arc, formed to the east from 20 to $9 \mathrm{Ma}$ and was isolated when spreading began in the Mariana back arc basin

\footnotetext{
${ }_{2}^{1}$ U. S. Geological Survey, Menlo Park, Califomia.

2 University of Hawaii, Honolulu.

${ }^{3}$ Department of Geological Sciences, Durham University, Durham, England.

${ }^{4}$ Institute of Oceanographic Sciences, Wormley, Surrey, England.
}

Copyright 1992 by the American Geophyscial Union.

Paper number 92JB01079.

0148-0227/92/92JB-01079\$05.00 (or Mariana Trough [Hussong and Fryer, 1981]). The modern Mariana Island Arc has been active since 5 to $6 \mathrm{Ma}$ coincident with the opening of the Mariana back arc basin (Figure 1); [Karig, 1971; Hussong and Uyeda, 1981].

The region around site 781 from $18^{\circ}$ to $21^{\circ} \mathrm{N}$ is tectonically active and characterized by steep faulting between blocks in the forearc [Mrozowski et al., 1981; Marlow et al., 1990]. For instance, a large, uplifted plateau is on strike with the northeast-trending fault that bounds the graben adjacent to site 781 [Fryer and Hussong, 1985]. The plateau overlies the westward extension of a chain of Pacific seamounts that are gradually being subducted.

\section{Seismic Stratigraphy}

Seismic reflection profiles between sites $780\left(19^{\circ} 32.5^{\prime} \mathrm{N}\right.$, $\left.146^{\circ} 39.2^{\prime} \mathrm{E}\right)$ and $781\left(19^{\circ} 37.9^{\prime} \mathrm{N}, 146^{\circ} 32.5^{\prime} \mathrm{E}\right)$ in the Mariana forearc during leg 125 reveal an anomalously bright reflection within a horst on the edge of a small graben located about 13 $\mathrm{km}$ northwest of Conical Seamount (Figures 1-5; [Marlow et al., 1990]). Two seismic reflection profiles across the horst confirmed a high-amplitude reflection located about 85 milliseconds below sea floor (msbsf) (Figures 4-5). The reflection was first penetrated by the drill at $72 \mathrm{~m}$ below the seafloor (mbsf) at site 781 and found to be a basalt unit between 12.7 and $25 \mathrm{~m}$ thick (poor core recovery at its base did not allow us to measure thickness accurately [Fryer et al., 1990]). The 72-m-thick sedimentary sequence overlying the basalt has an average velocity of $1505 \mathrm{~m} / \mathrm{s}$ [Marlow et al., 1990]. The layered reflections below the basalt on Lines 4 and 5A (Figures 4-5) are presumably from sedimentary sequences underlying the basalt.

\section{AGE OF THE BASALT}

The drill encountered three stratigraphic units at site 781: an upper sedimentary unit extending from the sea floor to a depth 


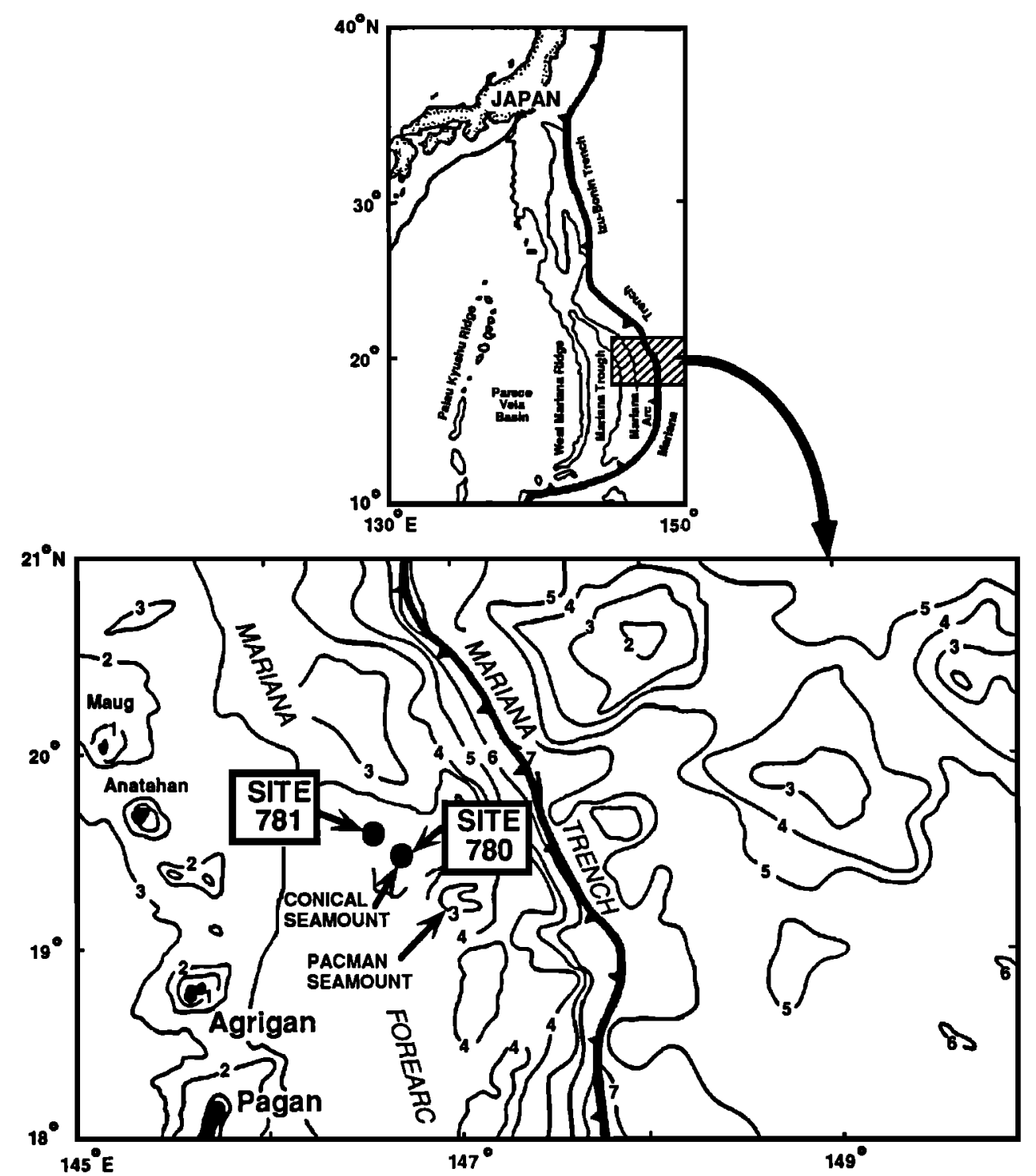

Fig. 1. Location of site 781. (Top) the regional setting of the Izu-Bonin and Marianas regions. (Bottom) detailed setting of site 781 showing the location of Agrigan and Pagan Islands and Conical and Pacman Seamounts. Bathymetric contours in kilometers.

of 72 mbsf, followed by a vesicular, porphyritic basalt layer to about 92 mbsf, that in turn is underlain by a second sedimentary unit that extends at least to the bottom of the hole at 250 mbsf. The upper sedimentary unit consists of late Pliocene (CN12b calcareous nannofossil zone of Okada and $B u k r y,[1980])$ to Holocene diatom-radiolarian silty-clay that grades downward into vitric silty-clay and vitric clayey silt [Fryer et al., 1990]. The lower sedimentary unit comprises early(?) Pliocene to late Pliocene (Nannofossil Subzone CN12b) vitric silty clay and vitric clayey silt [Fryer et al., 1990]. The Pliocene sedimentary unit overlying the basalt shows no evidence of thermal baking. The basal contact between the basalt and underlying Pliocene sediment was not recovered during coring operations.

Two K-Ar ages were determined at the U.S. Geological Survey (by L. B. G. Pickthorn, Menlo Park). Ages were calculated from six $\mathrm{K}_{2} \mathrm{O}$ analyses and two argon (Ar) analyses run on unaltered plagioclase separates from selected basalt core samples. The $\mathrm{K}_{2} \mathrm{O}$ analyses were $0.084,0.079,0.075,0.075,0.081$, and $0.082 \mathrm{wt} \%$ and averaged $0.079 \pm 0.004 \mathrm{wt} \%$. The first $\mathrm{Ar}$ analysis had $5.0 \%$ of radiogenic ${ }^{40} \mathrm{Ar}$ and yielded an age of $1.58 \pm 0.40 \mathrm{Ma}$. The second Ar analysis had $2.1 \%$ of radiogenic $40 \mathrm{Ar}$ and yielded an age of $1.93 \pm 0.62 \mathrm{Ma}$. The errors are estimates of the standard deviations of analytical precision (calculated using the methods of Cox and Dalrymple [1967] and Taylor [1982]) and are large because of the high error resulting from a low proportion of radiogenic to atmospheric argon 40, a common problem in young igneous rocks. The average of the two analyses, weighted by the inverse of the variances of the individual runs, gives an age of $1.68 \pm 0.37 \mathrm{Ma}$.

All the recovered basalt cores are reversely polarized. The $\mathrm{K}$ Ar dating indicates that the rocks cooled through the Curie temperature during the Matuyama Reversed-Polarity Chron (0.8 to $2.5 \mathrm{Ma}$ [Fryer et al., 1990]). The late Pliocene (Nannofossil Subzone CN12b, about $2.5 \mathrm{Ma}$ ) sedimentary layers directly above and below the basalt layer are normally magnetized and, on the basis of their paleontologic ages, were deposited during the older Gauss Normal Polarity Chron [Fryer et al., 1990] or more than $2.5 \mathrm{Ma}$. The age and magnetic data support the interpretation that the basalt unit is a sill. The uniform 


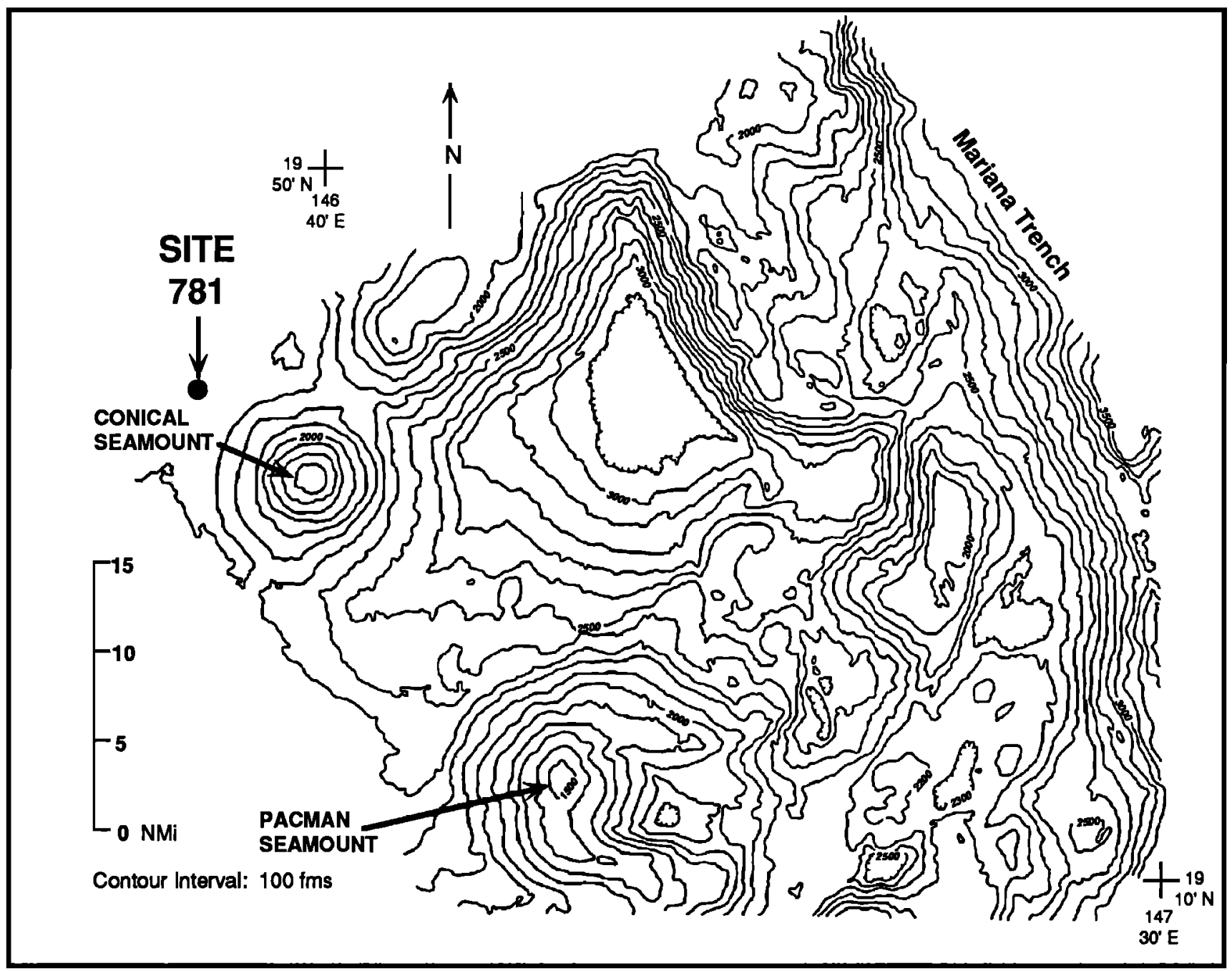

Fig. 2. Detailed bathymetric map of the outer Marianas forearc near site 781 and Conical Seamount. Bathymetric contours in fathoms (data are from re-digitized SeaMARC, SeaBeam, and 3.5-kHz records).

magnetization, petrology, and geochemistry of the basalt drill core samples and their schlieren-like structures suggest that the cores are from one continuous sill emplaced at the edge of a graben.

\section{Petrography AND GeOchemistry OF SITE 781 BasalT}

\section{Petrography}

The basalt sill is predominantly hypocrystalline having intersertal and intergranular to subophitic textures. Vesicles range from 0.1 to $4 \mathrm{~mm}$ in diameter and make up $5 \%$ to $10 \%$ of the rock. An 8-mm-thick, vesicle-free chill zone is present at the top of the sill, and sparse, very fine-grained, crystal-free zones are present throughout the sill. The basalt is fresh except where the glass matrix is partially replaced by amorphous clay at the base of the recovered unit. Glomerocrysts up to $5 \mathrm{~mm}$ in diameter are common and are frequently composed solely of plagioclase, although about one-third include clinopyroxene and sparse olivine. Opaque phases are present in about $40 \%$ of the glomerocrysts. Individual plagioclase crystals in glomerocrysts are typically euhedral to subhedral laths that range from 0.3 to $1.5 \mathrm{~mm}$ in length. Single euhedral plagioclase phenocrysts frequently exhibit normal, reverse, and oscillatory zoning, with evidence for relict cores and irregular (partly resorbed?) crystal boundaries.

Clinopyroxene phenocrysts are 0.1 to $0.4 \mathrm{~mm}$ in diameter, rounded to subhedral, and often have irregular crystal boundaries. The absence of a quench texture suggests they were not in equilibrium with the surrounding melt when the sill cooled. Single clinopyroxene crystals often contain fractures filled with glass. Olivine is ubiquitous as small, rounded, anhedral crystals that are usually fractured and altered. Magnetite is common as angular to irregular crystals $(<0.05$ $\mathrm{mm}$ ), increases in abundance downcore, and is infrequently included in single plagioclase or pyroxene grains. This crystal assemblage is set in a fine-grained groundmass of plagioclase, clinopyroxene and olivine microlites, that are in turn set in a dark brown glass. The modal percentage of plagioclase increases toward the center of the basalt unit from $21 \%$ to $31 \%$ and then decreases toward the base to $24 \%$. Clinopyroxene ranges from $1.2 \%$ to $5 \%$ and does not vary systematically throughout the core. Opaque phases comprise $3.0 \%$ to $4.5 \%$ and olivine is $<1.5 \%$. Glass + matrix (clinopyroxene + plagioclase) accounts for $55 \%$ to $65 \%$ of the rock; locally, glass comprises $20 \%$ to $45 \%$, plagioclase $20 \%$ to $25 \%$, and clinopyroxene $20 \%$ to $25 \%$. 


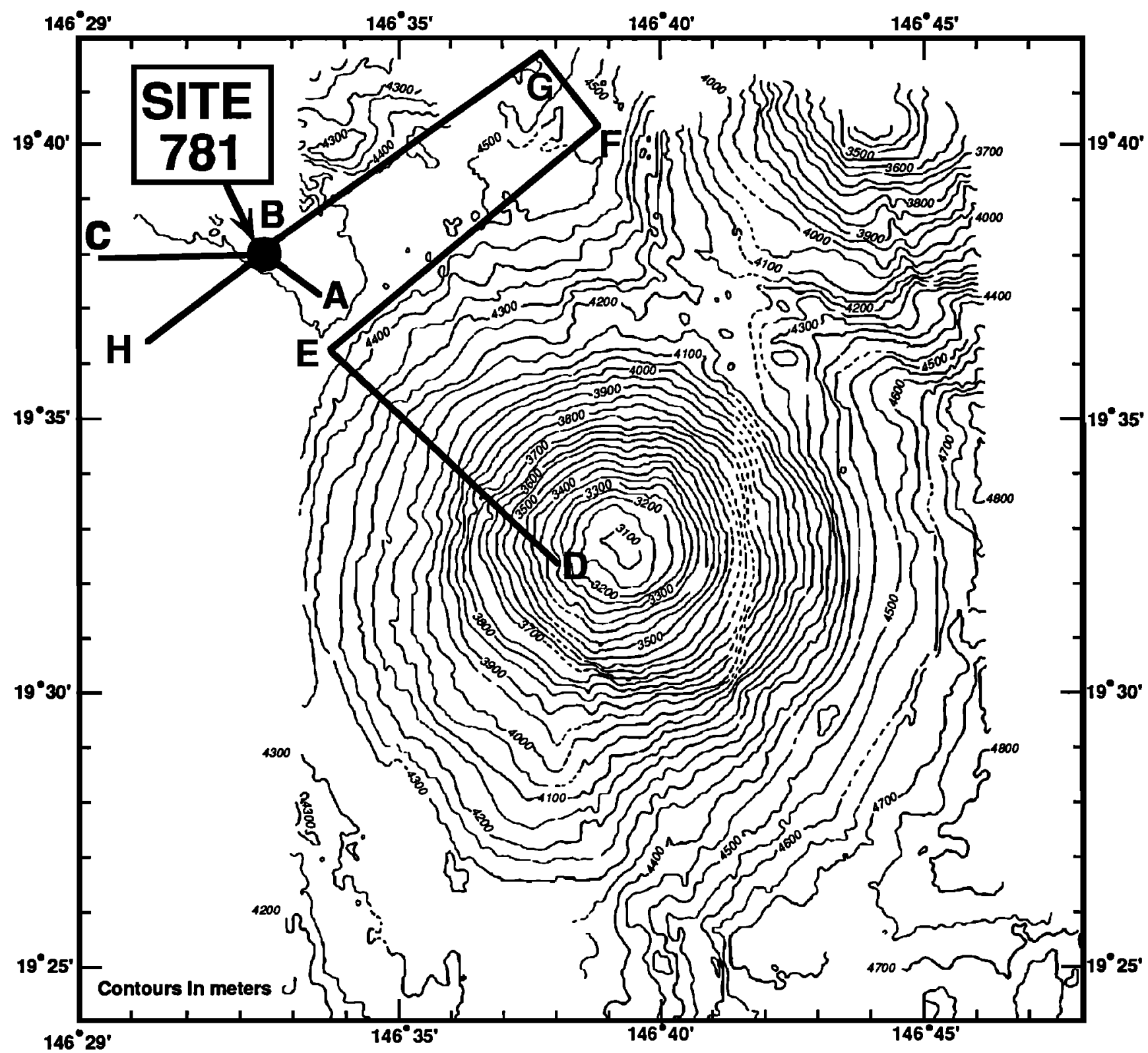

Fig. 3. Trackline map of seismic reflection profiles across site 781 and Conical Seamount. Detailed bathymetry based on unpublished SeaBeam data collected by the University of Kiel. Contours in meters.

\section{Analytical Procedures}

Geochemical data for the basalt samples from site 781 are given in Table 1. Major and trace element analyses of eight whole rock samples were analyzed by $X$ ray fluorescence (XRF) both on board the JOIDES Resolution (JR) and at the University of Hawaii (UH) (Table 1). Rare earth element (REE) analyses of three samples were performed at Lamont-Doherty Geological Observatory (LDGO) by directly coupled plasma (DCP) spectrometry. Analytical techniques are described below and detailed descriptions of techniques for the $\mathrm{J}$ analyses are described in Fryer et al. [1990].

Powders were prepared from rocks washed in distilled water, chipped to pieces less than $0.5 \mathrm{~cm}$ in size, and powdered in an alumina mill (UH) or a tungsten carbide (WC) mill (JR). Fused glass disks (major elements) and pressed powder pellets (trace elements) were prepared and on-line data reduction accomplished using the methods of Norrish and Hutton [1969] and Norrish and Chappell [1977]. Glass disks were prepared from rock powders ignited at $950^{\circ} \mathrm{C}$ (UH) or $1030^{\circ} \mathrm{C}$ (JR) to drive off volatiles, mixed with a lithium metaborate flux, and fused at $1000^{\circ} \mathrm{C}$ (UH) or $1150^{\circ} \mathrm{C}(\mathrm{JR})$. Volatiles are listed in Table 1 as loss on ignition (LOI). Pressed pellets were prepared from $\sim 5 \mathrm{~g}$ of rock powder, mixed with a polyvinyl alcohol binder and pressed into a boric acid casing (UH) or an aluminum cap (JR). Two systematic errors were observed in the JR data. $\mathrm{Na}_{2} \mathrm{O}$ values have been corrected for all samples in Table 1 either by new analyses or by using an empirical factor; see Fryer et al. [1992] for a complete discussion. $\mathrm{TiO}_{2}$ values have not been corrected.

REE analyses at LDGO were performed on rock powders ignited at $950^{\circ} \mathrm{C}$, mixed with an ultrapure lithium metaborate (Mathey-Johnston, Puratronic) flux, fused in a graphite crucible at $1060^{\circ} \mathrm{C}$ and dissolved in $1 \mathrm{~N} \mathrm{HCl}$. This solution was 


\section{LINE 4}
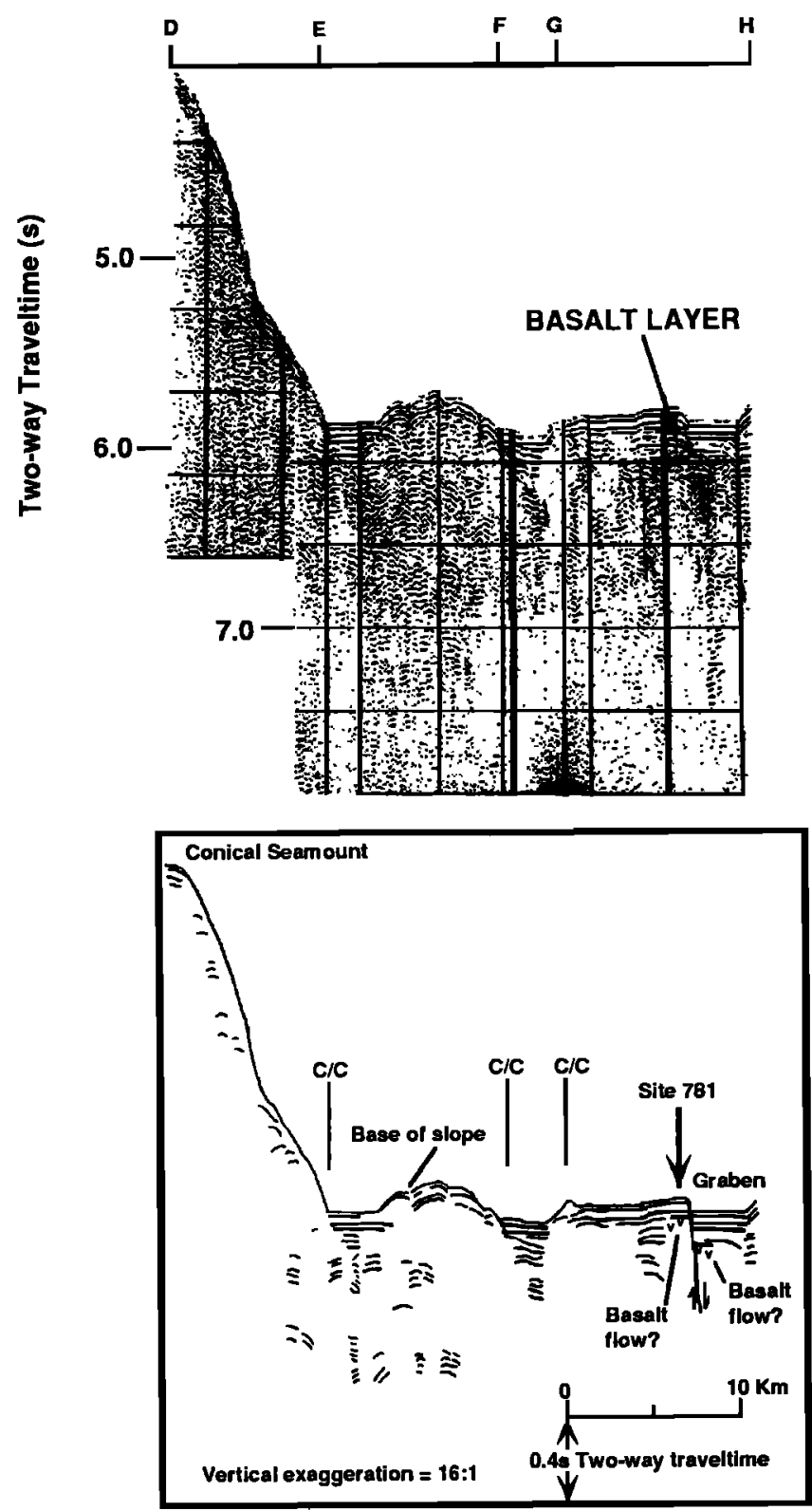

Fig. 4. Seismic reflection profile across the flank and along the base of Conical Seamount and across site 781 and an adjacent graben, with an interpretative drawing of the profile. The high-amplitude reflector at about $85 \mathrm{~ms}$ (two-way traveltime) corresponds to the top of the basalt layer penetrated at site 781 at $72 \mathrm{mbsf}$. A similar reflector in the adjacent graben is also interpreted as a volcanic layer. The two reflectors may be part of one volcanic unit that is either displaced by young faulting, as indicated here, or is continuous and joined out of the plane of this section. The latter hypothesis requires that the sill be intruded at two different depths in the graben and adjacent horst block (see Figure 5 and text for discussion). The trackline location is shown in Figure 3.

filtered to remove graphite particles and washed onto cation exchange columns (filled with $200-400$ mesh analytical grade resin) for REE separation. REE concentrated samples were dried overnight in teflon beakers, re-dissolved in a $1 \mathrm{~N} \mathrm{HNO}_{3}$ solution spiked with $K, P$, and $B e$; and analyzed by DCP spectrometry. The $P$ and $B e$ were used as internal standards to correct for short-term drift, while $\mathbf{K}$ acted as a signal enhancer. Distilled reagent grade acids diluted with ultrapure water were used for all phases of REE analyses. Data reduction included blank subtraction, correction for long and short term drift, and known elemental interferences. Absolute abundances were determined by comparison to two basaltic standards (K1919 and AII-92-29), and precision was determined from repeat analyses of several samples as unknowns. The precision for repeat analyses of a mid-Atlantic ridge basalt has $<2 \%$ standard deviation $\{(1$ standard deviation/average value $) \times 100\}$ for all elements [Fryer et al., 1992]. Because of a random, sporadic La contamination problem, the La values for all samples are suspect and have been included only where independent or duplicate information is available.

The basalt was also analyzed for incompatible trace elements by inductively coupled plasma/mass spectrometry (ICP-MS) at Durham University and for $\mathrm{Sr}, \mathrm{Nd}$ and $\mathrm{Pb}$ isotopic ratios by mass spectrometry at Royal Holloway and Bedford New College, London (for analytical methods see Fryer et al., [1992]).

\section{Geochemistry}

Abundances of major elements in the site 781 lavas are similar to, but not exactly like, those typically found in Mariana Island Arc tholeiite basalts [Stern et al., 1989; Lin et $a l ., 1989]$ and are typical of IAT basalts. Samples from site 781 are classified as basalt and plot within the low-K tholeiite field on a $\mathrm{SiO}_{2}-\mathrm{K}_{2} \mathrm{O}$ classification diagram (Figure 6). Samples

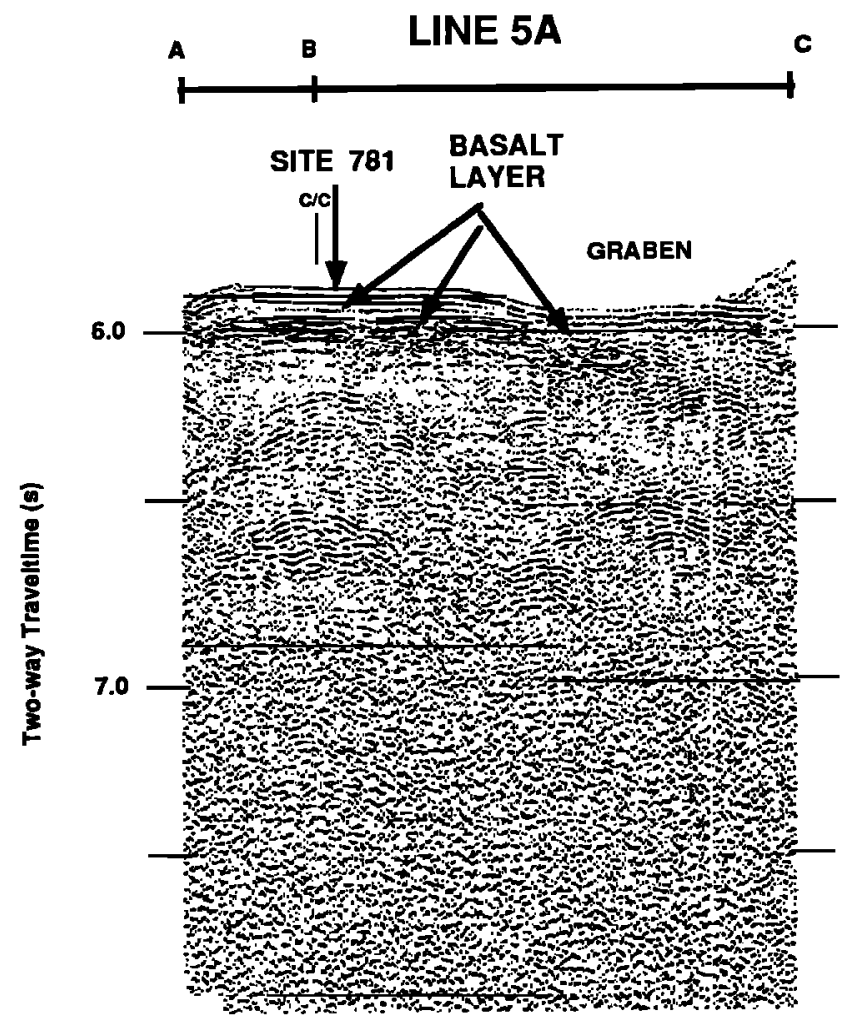

Fig. 5. Processed, digital, seismic reflection data collected from survey Line 125-05A after leaving site 781. Automatic gain control (AGC) was applied and the processing filter parameters were 25 to $140 \mathrm{~Hz}$, with a filter length of $37 \mathrm{~Hz}$. The high-amplitude reflector corresponds to the basalt layer drilled at site 781 , which can be traced laterally beneath the adjacent graben. The trackline location is shown in Figure 3. 
TABLE 1a. Geochemical Properties of ODP Site 781 Basalt Samples: Leg 125, Site 781. Basalt Layer, XRF Whole Rock Major and Trace Element Abundances

\begin{tabular}{|c|c|c|c|c|c|c|c|c|}
\hline \multicolumn{9}{|c|}{ Core } \\
\hline & $\begin{array}{c}8 \mathrm{RCC} \dagger \\
11-13 \mathrm{~cm}\end{array}$ & $\begin{array}{c}9 \mathrm{R} 1 \dagger \\
69-71 \mathrm{~cm}\end{array}$ & $\begin{array}{c}9 \mathrm{R} 2 \dagger \\
49-51 \mathrm{~cm}\end{array}$ & $\begin{array}{c}9 R 3 \ddagger \\
88-92 \mathrm{~cm}\end{array}$ & $\begin{array}{c}10 \mathrm{R} 1 \dagger \\
84-86 \mathrm{~cm}\end{array}$ & $\begin{array}{l}10 \mathrm{R} 2 \dagger \\
68-72 \mathrm{~cm}\end{array}$ & $\begin{array}{r}10 \mathrm{R} 3 \dagger \\
65-67 \mathrm{~cm}\end{array}$ & $\begin{array}{c}10 \mathrm{R} 1 \ddagger \\
131-135 \mathrm{~cm}\end{array}$ \\
\hline $\mathrm{SiO}_{2}$ & 49.89 & 49.56 & 49.09 & $\begin{array}{c}\text { Oxides, wt \% } \\
50.29\end{array}$ & 50.46 & 49.53 & 50.35 & 50.73 \\
\hline $\mathrm{TiO}_{2}$ & 0.86 & 0.88 & 0.85 & 0.91 & 0.89 & 0.85 & 0.90 & 0.91 \\
\hline $\mathrm{Al}_{2} \mathrm{O}_{3}$ & 17.87 & 17.69 & 17.31 & 17.79 & 17.10 & 17.57 & 17.28 & 18.17 \\
\hline $\begin{array}{l}\mathrm{Fe}_{2} \mathrm{O}_{3}^{*} \\
\mathrm{MnO}\end{array}$ & $\begin{array}{r}12.09 \\
0.25\end{array}$ & $\begin{array}{r}12.43 \\
0.23\end{array}$ & $\begin{array}{r}12.03 \\
0.25\end{array}$ & $\begin{array}{r}12.45 \\
0.20\end{array}$ & $\begin{array}{r}12.36 \\
0.24\end{array}$ & $\begin{array}{r}12.02 \\
0.22\end{array}$ & $\begin{array}{r}12.73 \\
0.24\end{array}$ & $\begin{array}{l}11.93 \\
0.18\end{array}$ \\
\hline $\mathrm{MgO}$ & 4,21 & 4.40 & 4.45 & 4.64 & 4.25 & 4.45 & 4.45 & 4.56 \\
\hline $\mathrm{CaO}$ & 11.18 & 11.32 & 11.09 & 11.13 & 10.95 & 11.08 & 10.89 & 11.24 \\
\hline $\mathrm{Na}_{2} \mathrm{O}^{*}$ & 2.10 & 2.02 & 2.08 & 2.27 & 2.16 & 2.31 & 2.19 & 2.21 \\
\hline $\mathrm{K}_{2} \mathrm{O}$ & 0.52 & 0.42 & 0.43 & 0.42 & 0.58 & 0.39 & 0.50 & 0.35 \\
\hline $\mathrm{P}_{2} \mathrm{O}_{5}$ & 0.06 & 0.06 & 0.06 & 0.10 & 0.06 & 0.06 & 0.06 & 0.10 \\
\hline Total & 99.03 & 99.01 & 97.64 & 100.20 & 99.05 & 98.48 & 99.59 & 100.38 \\
\hline LOI & 0.64 & 1.28 & 0.86 & $\mathrm{nd}^{*}$ & 1.95 & 0.75 & 0.79 & $\mathrm{nd}^{*}$ \\
\hline \multicolumn{9}{|c|}{ Trace elements, ppm } \\
\hline $\mathrm{Nb}$ & 1 & 1 & 1 & 1 & 1 & 1 & 1 & 1 \\
\hline $\mathbf{Z}$ & 48 & 46 & 46 & 47 & 52 & 46 & 49 & 48 \\
\hline$\overline{\mathbf{Y}}$ & 23 & 22 & 22 & 21 & 24 & 22 & 23 & 22 \\
\hline $\mathrm{Sr}$ & 294 & 294 & 295 & 287 & 288 & 294 & 293 & 285 \\
\hline $\mathrm{Rb}$ & 7 & 6 & 4 & 8 & 13 & 2 & 7 & 3 \\
\hline $\mathbf{Z n}$ & 98 & 92 & 71 & 90 & 94 & 77 & 82 & 78 \\
\hline G & 175 & 184 & 72 & 197 & 181 & 141 & 196 & 133 \\
\hline $\mathrm{Ni}$ & 7 & 9 & 10 & 11 & 11 & 11 & 10 & 12 \\
\hline $\mathrm{Cr}_{\mathrm{r}}$ & 11 & 11 & 11 & 43 & 8 & 9 & 11 & 19 \\
\hline $\mathbf{v}$ & 407 & 428 & 387 & 374 & 354 & 408 & 370 & 392 \\
\hline $\mathrm{Ce}$ & 18 & 32 & 15 & nd & 17 & 26 & 23 & nd \\
\hline $\mathbf{B a}$ & 169 & 142 & 165 & 196 & 158 & 280 & 177 & 159 \\
\hline
\end{tabular}

†Analyses performed on board the D/V Joides Resolution; analyst, D. Sims.

$\ddagger$ Analyses performed at the University of Hawaii; analysts, T. Husslebosch and L. Johnson.

${ }^{*} \mathrm{Fe}_{2} \mathrm{O}_{3}$ is total iron calculated as $\mathrm{Fe}_{2} \mathrm{O}_{3} ; \mathrm{Na}_{2} \mathrm{O}$ values for analyses performed on board the $\mathrm{D} / \mathrm{V}$ Joides Resolution corrected on the basis of factor determined by R. Arculus et al. (unpublished data, 1991); nd, not determined.

show a moderate degree of iron enrichment and plot in the tholeiite field on an AFM diagram (Figure 7). These samples have abundances of $\mathrm{SiO}_{2}\left(49.09-50.73\right.$ wt. \%), high $\mathrm{Al}_{2} \mathrm{O}_{3}$ (17.28 - 18.17 wt. \%) and high $\mathrm{Fe}_{2} \mathrm{O}_{3} *(11.93-12.73$ wt. \%; $\mathrm{Fe}_{2} \mathrm{O}_{3}{ }^{*}=$ total iron calculated as $\mathrm{Fe}_{2} \mathrm{O}_{3}$ ) coupled with low $\mathrm{MgO}(4.21-4.56 \mathrm{wt} \%$ ), which is a common characteristic of the IAT series. The basalt chemistry closely resembles the lower-potassium tholeiitic lavas of Guguan, Asuncion, and the submarine volcanoes of the southern Mariana arc and are very different from the higher-potassium calc-alkaline lavas of Agrigan and Pagan [Dixon and Batiza, 1979; Stern et al., 1989; Woodhead, 1988; Lin et al., 1989] (Figures 6 and 7), or the

TABLE 1b. Geochemical Properties of ODP Site 781 Basalt Samples: ODP Leg 125, Site 781, Basalt Layer, REE Analyses of Three Representative Samples

\begin{tabular}{|c|c|c|c|c|c|}
\hline Interval & $\begin{array}{c}9 \mathrm{R} 1 \\
69-71 \mathrm{~cm}\end{array}$ & $\begin{array}{c}10 \mathrm{R} 2 \\
68-71 \mathrm{~cm}\end{array}$ & $\begin{array}{c}10 \mathrm{R} 3 \\
65-67 \mathrm{~cm}\end{array}$ & $\begin{array}{c}\text { S.d., } \\
\%\end{array}$ & $\begin{array}{l}\text { Factor } \\
\text { Nom. }\end{array}$ \\
\hline $\mathrm{La}$ & 2.89 & 3.37 & 3.17 & na & 0.315 \\
\hline$\overline{C e}$ & 8.54 & 9.11 & 9.46 & 1.9 & 0.813 \\
\hline $\mathbf{N}$ & 6.19 & 7.60 & 7.44 & 1.7 & 0.597 \\
\hline Sm & 2.09 & 2.51 & 2.42 & 1.9 & 0.192 \\
\hline En & 0.81 & 0.92 & 0.92 & 0.5 & 0.072 \\
\hline Gd & 2.92 & 2.99 & 3.18 & 0.4 & 0.259 \\
\hline Dy & 2.80 & 3.58 & 3.48 & 1.6 & 0.325 \\
\hline $\mathrm{Er}$ & 1.82 & 2.56 & 2.23 & 1.2 & 0.214 \\
\hline $\mathbf{Y b}$ & 1.80 & 2.26 & 2.20 & 1.6 & 0.208 \\
\hline Ln & 0.30 & 0.36 & 0.34 & 1.9 & 0.032 \\
\hline
\end{tabular}

Data determined by directly coupled plasma (DCP), at Lamont-Doherty Geological Observatory; analyst, L. Johnson. Values are in ppm; na, La values not determined.

* Percentage of standard deviation [(1 standard deviation /average)*100] for four analyses of a Mid-Atlantic ridge basalt.

tChondrite factor used for nomalization for Figure 2. 
TABLE 1c. Geochemical Properties of ODP Site 781 Basalt Samples: ODP Leg 125, Site 781, Basaltic Layer, Incompatible Elements, REE, and Isotopic Values for Sample: $781-9 \mathrm{R} 1,72-77 \mathrm{~cm}$

Value

Incompatible Elements, ppm

$\begin{array}{cc}\mathrm{Zr} & 43 \\ \mathrm{Y} & 19.4 \\ \mathrm{Nb} & 1.8 \\ \mathrm{Hf} & 1.37 \\ \mathrm{Ta} & 0.12 \\ \mathrm{~Pb} & 2.52 \\ \mathrm{Th} & 0.18 \\ \mathrm{U} & 0.20 \\ \mathrm{Sr} & 270 \\ \mathrm{Ba} & 156\end{array}$

$R E E,{ }^{*} p p m$

$\begin{array}{cl}\mathrm{La} & 3.62 \\ \mathrm{Ce} & 7.64 \\ \mathrm{Pr} & 1.2 \\ \mathrm{Nd} & 6.15 \\ \mathrm{Sm} & 2.16 \\ \mathrm{Eu} & 0.79 \\ \mathrm{G} & 2.73 \\ \mathrm{~Tb} & 0.43 \\ \mathrm{Dy} & 2.84 \\ \mathrm{Ho} & 0.60 \\ \mathrm{Er} & 1.70 \\ \mathrm{Tm} & 0.30 \\ \mathrm{Yb} & 1.79 \\ \mathrm{In} & 0.30\end{array}$

Isotopic Ratiost

$\begin{array}{lc}{ }^{87} \mathrm{Sr} /{ }^{86} \mathrm{Sr} & 0.703487 \stackrel{ \pm}{-} 10 \\ { }^{143} \mathrm{Nd} /{ }^{144} \mathrm{Nd} & 0.513048 \stackrel{ \pm}{-} \\ { }^{206} \mathrm{~Pb} / 20{ }^{204} \mathrm{~Pb} & 18.740 \\ { }^{207} \mathrm{~Pb} / 204 \mathrm{~Pb} & 15.569 \\ { }^{208} \mathrm{~Pb} / 204 \mathrm{~Pb} & 38.386\end{array}$

* ICP-MS, performed at Durham University; Analyst, B. Murton †Mass spectrometer, performed at Royal Holoway and Bedford New College, London. The sample was leached in $6 \mathrm{~N} \mathrm{HCl}$ for 3 hours at $180^{\circ} \mathrm{C}$ for Sr isotope analysis. Analyst, J. A. Pearce. shoshonitic and high $K$ calc-alkaline lavas in the seamount province of the northern Mariana Island Arc [Bloomer et al., 1989].

Compositional variations in the basalt samples are small: positive covariations in $\mathrm{CaO}$ and $\mathrm{Al}_{2} \mathrm{O}_{3}$ that are inversely correlated with covariations in $\mathrm{MgO}_{\mathrm{g}} \mathrm{O}$ a $\mathrm{Fe}_{2} \mathrm{O}_{3}{ }^{*}$ (total iron) can be explained simply by variation in the proportion of phenocrysts of plagioclase feldspar or mafic phases; a small part of the variation in potassium can be related to alteration. The data are consistent with a single, chemically homogeneous intrusion, and we find little evidence for internal fractionation.

Compatible trace elements ( $\mathrm{Sr}, \mathrm{V}, \mathrm{Cr}, \mathrm{Ni}$ ) show a similar pattern to the major elements with small variations that probably relate to the relative proportion of plagioclase and mafic phenocrysts. As in the case of $\mathrm{K}$, the mobile elements $\mathrm{Rb}, \mathrm{Ba}, \mathrm{Cs}$ show small variations that may be related to alteration. REE patterns from three samples representing the top, center, and base of the recovered basalt are essentially flat at about 10 times chondrite (Figure 8). The patterns show a slight LREE and HREE depletion that gives a "humped" effect. The shallowest sample analyzed has slightly lower abundances than the deeper samples and a more distinct, heavy REE depletion. The patterns fall at the lower end of the range of active Mariana arc lava patterns (Figure 8) [Stern et al., 1989], which vary from flat to LREE-enriched; the latter in particular have distinct negative $\mathrm{Ce}$ anomalies that are not apparent in the site 781 basalt.

The incompatible trace-element characteristics can be portrayed using multielement plots, normalized to N-MORB (normal mid-ocean ridge basalt) [Pearce, 1983]. On such a diagram, magmas derived from a depleted mantle source similar to a MORB source will show a flat pattern. Magmas derived from the mantle overlying a subducting slab typically give patterns that are depleted in the incompatible HFS elements $(Y$, $\mathrm{Ti}, \mathrm{Zr}$ and the middle-heavy REE) and are selectively enriched in the LIL elements ( $\mathrm{Sr}, \mathrm{K}, \mathrm{Rb}, \mathrm{Ba}$ and usually also light REE and Th) that are derived from the subducted oceanic lithosphere and its sediment cover through dehydration and partial melting. The type of enrichment pattern will also vary from arc to arc

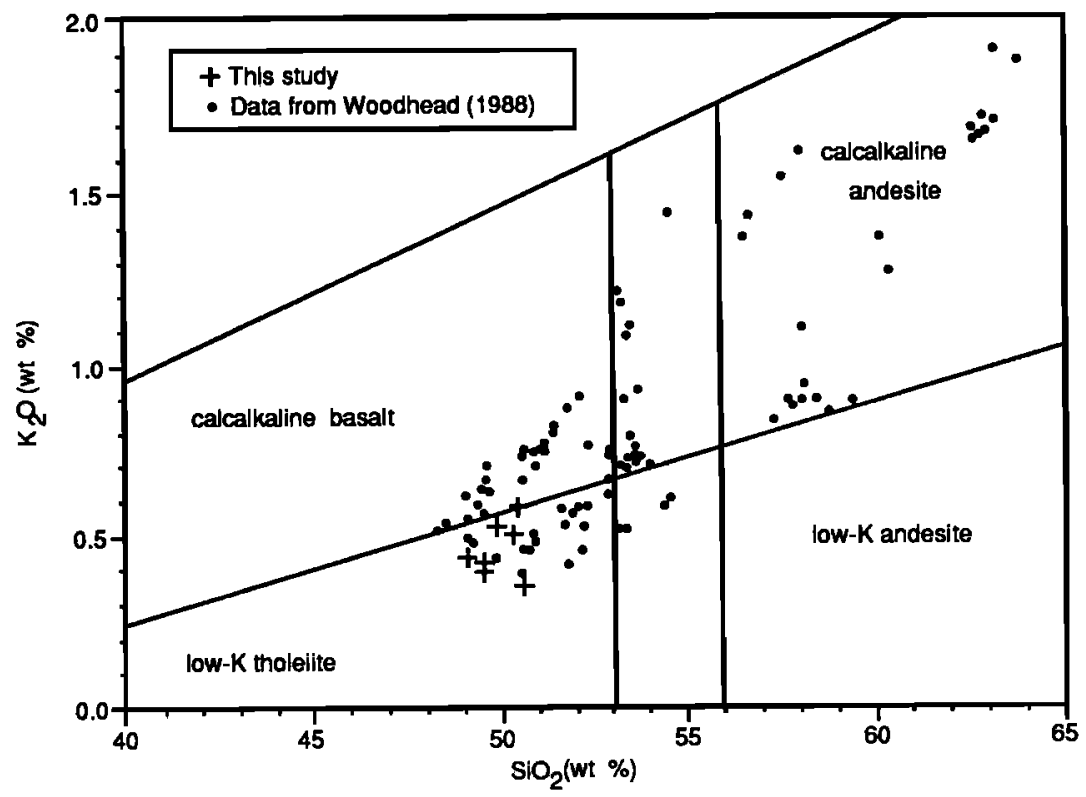

Fig. 6. Classification of the basalt sill at site 781, based on potassium-silica covariation. Fields are from Peccerillo and Taylor [1976]. Dots are analyses of active Mariana arc volcanics [Woodhead, 1988]. 


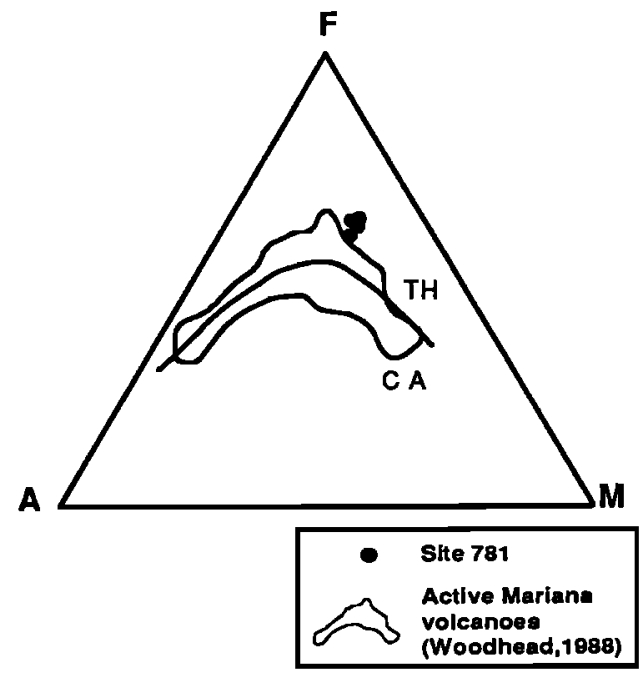

Fig. 7. Classification of the basalt sill on the basis of Fe enrichment. The dividing line is from Irvine and Barager [1971]. Irregular outline represents analyses of active Mariana arc volcanics [Woodhead, 1988].

according to the nature of material being subducted, and with the thermal and geodynamic parameters of the subduction system [Gill, 1981; Pearce, 1983]. The MORB normalizing values used in Figure 9 are taken with slight modifications from the compilation by Sun and McDonough [1989], and the ordering of the elements (with the exception of $\mathrm{Sr}$ and $\mathrm{K}$ ) is based on the relative incompatibility (increasing from left to right) during lherzolite melting and is taken from Pearce [1983].

Patterns from four Mariana arc volcanoes, the forearc tholeiitic suite from DSDP site 459, and from the ODP site 781 rocks show selective enrichments (relative to N-MORBs) in all LIL elements from Sr through Th and relatively flat, though slightly depleted, patterns for the HFS elements (Hf-Yb, Figure 9). Agrigan Island and Fukujin Seamount are calc-alkaline volcanoes in the central and northem Mariana arc, respectively [Bloomer et al., 1989]. Esmerelda Bank and Ruby Seamount are submarine volcanoes in the southern Mariana arc that erupt lavas with some tholeiitic characteristics [Stern et al., 1989].

Abundances of $\mathrm{Sr}, \mathrm{K}$ and $\mathrm{Rb}$ are all lower for the basalt at site 781 than for the arc volcanoes (Figure 9); however, Ba content is in the range of the values for the arc volcanoes. The site $\mathbf{7 8 1}$ lavas most closely resemble the lavas from Ruby Seamount,

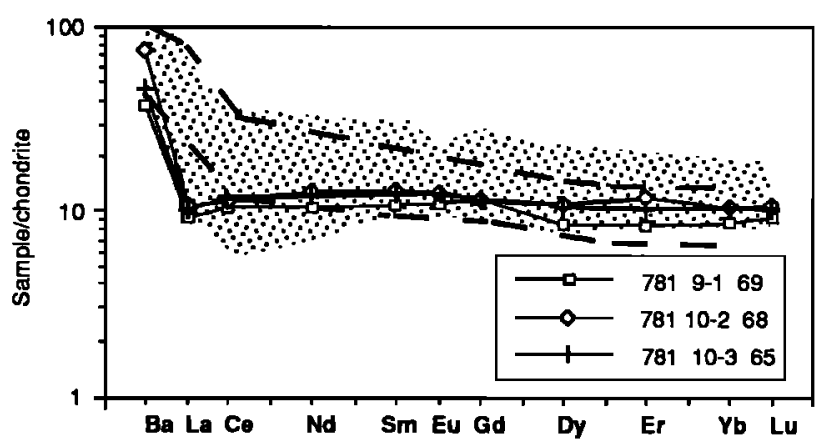

Fig. 8. Chondrite normalized REE patterns. The relatively flat pattem with a small "sway" in the middle REEs is characteristic of Mariana arc lavas. The fields are from the Mariana aerial (stippled) and submarine (dashed outline) volcanoes of Stern et al. [1989].

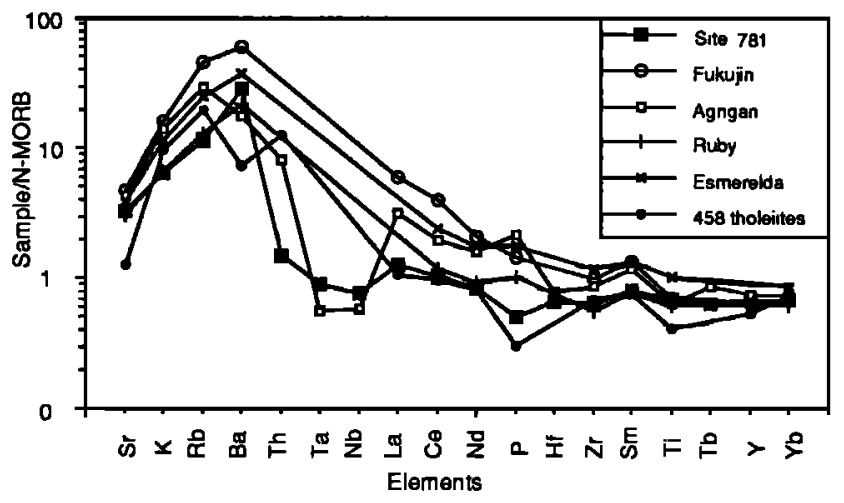

Fig. 9. MORB-normalized incompatible trace-element pattems for site 781 basalt in comparison to a nearby, active, subaerial volcano, Agrigan (J. A. Pearce, unpublished ICP-MS data, 1991), to DSDP hole 458 [Mattey et al., 1980; Wood et al., 1981], to submarine volcanoes Ruby and Esmerelda, in the southem Mariana arc [Stern et al., 1989], and to the submarine volcano Fukujin in the northem Mariana arc [Bloomer et al., 1989]. Normalizing values are from Sun and McDonough [1989] and Pearce [1983]. Data for site 781 samples are given in Table 1.

although $\mathrm{Ba}$ is slightly enriched and $\mathrm{P}$ slightly depleted in site 781 lavas relative to Ruby. Th is depleted and $\mathrm{Ta}$ and $\mathrm{Nb}$ enriched in the site 781 basalt relative to Agrigan and Pagan lavas. However, the site 781 basalt $\mathrm{Ta}$ and $\mathrm{Nb}$ plot as a markedly negative anomaly and $\mathrm{Ti}$ plots as a slightly negative anomaly on a MORB-normalized diagram (Figure 9), which is characteristic of subduction-related magmas. The negative anomalies are attributed either to separation of the REE and LILE from TA-Nb-Ti by aqueous fluids derived from the subducted slab [Hawkesworth et al., 1977; Pearce, 1983] or to stabilization of $\mathrm{Ta}-\mathrm{Nb}-\mathrm{Ti}$ phases in the source for these magmas [Venturelli et al., 1984; Greenough, 1988]. La in the site 781 basalt is depleted relative to Fukujin and Agrigan lavas but is the same as in samples from Ruby Seamount and in DSDP site 458 tholeiites. Site 781 lavas are slightly depleted in HFS elements (Hf- $\mathrm{Yb}$ ) relative to many of the arc volcanoes, but are similar to those from Ruby Seamount. Site 458 samples show similar patterns to the arc volcanoes although they are distinctly more depleted in $\mathrm{Ti}, \mathrm{P}$ and $\mathrm{Ba}$. Although the enrichment in the mobile LIL elements for samples from site 458 may be caused by alteration, the enrichments for the site 781 basalt and the arc volcanoes must be primary features.

The enrichment of the mobile elements $(\mathrm{Sr}, \mathrm{K}, \mathrm{Rb}$, and $\mathrm{Ba}$ ), relative to $\mathrm{N}-\mathrm{MORB}$, suggests that the magma source was in the mantle overlying, not beneath, the subducting plate. Because mobile elements (i.e.: $\mathrm{Sr}, \mathrm{K}, \mathrm{Rb}$, and $\mathrm{Ba}$ ) are released from subducted sediment and basaltic crust at subsolidus temperatures during prograde dehydration of the subducted slab, the source of these mobile elements in arc lavas must be at depths less than $50 \mathrm{~km}$ and is probably within the upper part of the subducted slab. Th and the LREEs are only mobilized when temperatures are higher, when sediment melting can take place. Thus they would be expected to be released from the subducted slab at greater depths. The higher Th and La content in Agrigan lavas than in the site 781 basalt may reflect a higher sediment contribution to the Agrigan source. The apparently lower sediment contribution to site 781 lavas may indicate a shallower source, perhaps trenchward of the source for Agrigan and Fukujin. The amounts of the HFS elements $(\mathrm{Y}, \mathrm{Zr}, \mathrm{Nb})$ in site 781 basalts are comparable with volcanic rocks from the 


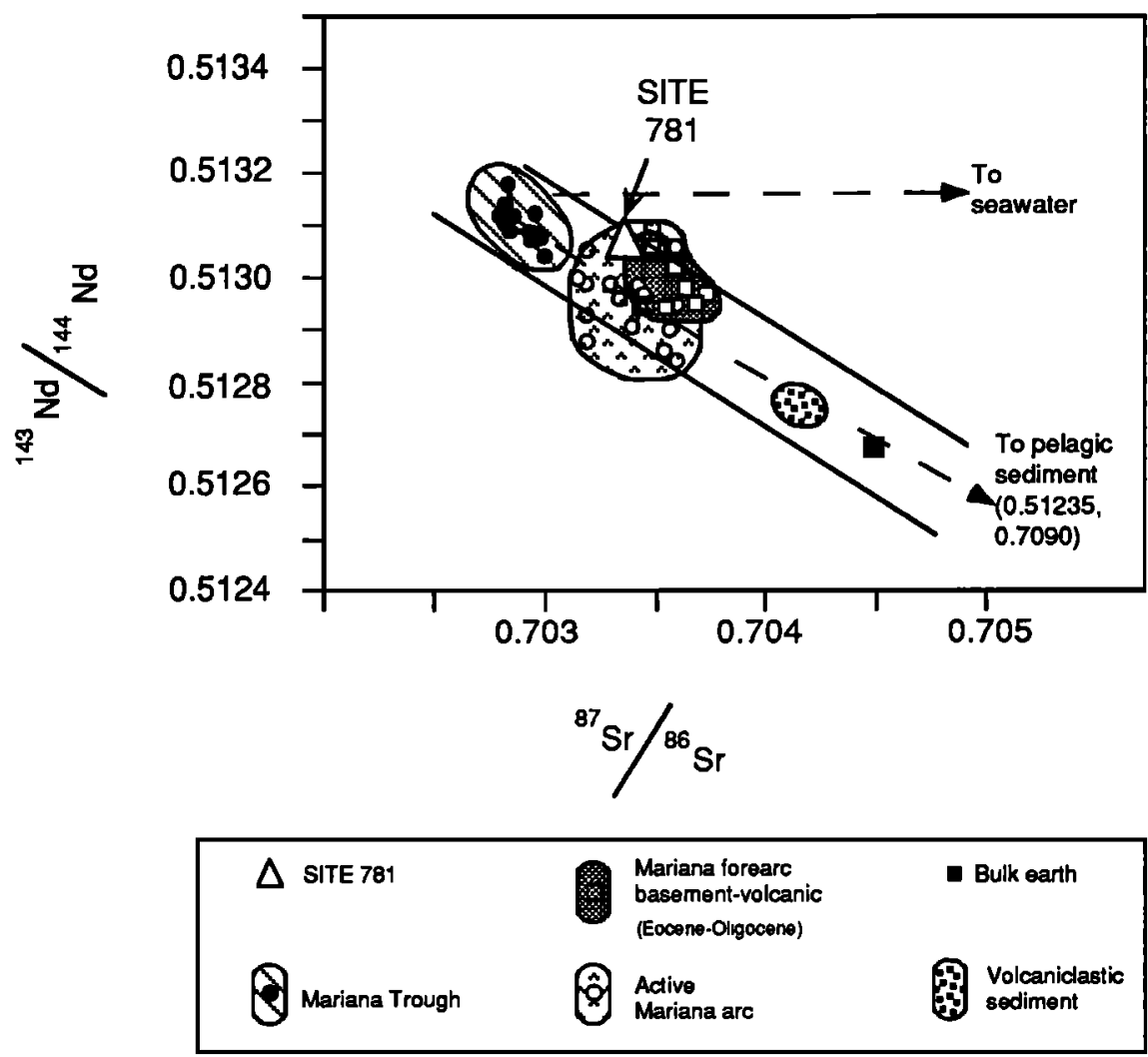

Fig. 10. Sr-Nd isotope covariation diagram for the basalt sill at site 781, in comparison to Eocene-Oligocene forearc boninitic-tholeiitic lavas and lavas from the Mariana Trough and active Mariana arc.

active arc. This suggests a like degree of melting and involvement of similar mantle for the origin of the sill as for the volcanoes in the active arc. The slightly lower abundances of the HFS elements in the dredged and previously drilled forearc sites suggest a slightly lower proportion of melting or a more depleted source than that for site 781 .

\section{Isotope Systematics}

Figure 10 compares $\mathrm{Sr}$ and $\mathrm{Nd}$ isotope ratios for site 781 basalts with isotope ratios for lavas from the active Mariana arc [Woodhead, 1989], Mariana Trough [Volpe et al., 1987], and from the Eocene to Oligocene Mariana forearc basement [Hickey-Vargas and Reagan, 1987; Hickey-Vargas, 1989]. Active arc rocks have higher $\mathrm{Sr}$ and lower Nd ratios than rocks from the Mariana Trough. The basalt from site 781 plots at the high end of the active arc field in terms of Nd isotope ratios, although its $\mathrm{Sr}$ isotope ratio is comparable.

In a $\mathrm{Pb}$-isotope diagram (Figure 11), the lavas from the active Mariana arc plot off the Northem Hemisphere Reference Line (NHRL) (the line containing MORB and northern hemisphere oceanic islands) of Hart [1984] toward pelagic sediments (or a mixture of pelagic and volcanogenic sediments). The Eocene to Oligocene forearc basement [Meijer, 1976, 1983] plots along or near the NHRL. The site 781 sample plots in the center of the active arc field.

\section{Discussion}

This basalt is the youngest in situ igneous layer reported in the Izu-Bonin and Mariana forearcs [Marlow et al., 1988], and its genesis is important for understanding the emplacement of volcanic rocks in forearc settings. Sedimentary strata recovered above and below the basalt have a biostratigraphic age of late Pliocene (Nannofossil Subzone CN12b). The mineralogy, texture, and chemistry of the site 781 basalt are remarkably constant throughout the unit. The compositional homogeneity and the absence of any distinct internal flow boundaries suggest that basalt formation was a single intrusive event. The contact between the basalt and upper sedimentary strata is a narrow glassy margin with no pillow structures or breccia. These observations, along with the $\mathrm{K}-\mathrm{Ar}$ age of $1.7 \mathrm{Ma}$, indicate that the basalt layer was injected in situ as a sill. The magma was probably intruded from the fault zone bounding the graben and then was quenched against the overlying sediment. Petrographic and geochemical evidence for interaction of the basalt with the overlying sediment are absent; however, low recovery (28\%-55\%) and a gap of $29 \mathrm{~m}$ following the last recovered rock at 92 mbsf [Fryer et al., 1990] may have prevented the identification of lower flow contacts.

Several models for the generation of igneous rocks in forearc settings have been discussed by Meijer [1980], Hussong and Uyeda [1981], Hickey and Frey [1982], Kobayashi [1983a,b], and Marlow et al. [1988]. However, as we shall see in the following discussion, none of the models offers a satisfactory explanation for the generation of basalt at site 781 .

An early model for generating forearc volcanic rocks is shown in Figure $12 a$ [from Hussong and Uyeda, 1981], and this model involves a vertical subarc magma source that formed when the subducting slab was seaward of its present location. This model would imply tectonic erosion of the older forearc, so that the site 781 basalt would now be in the forearc of a 

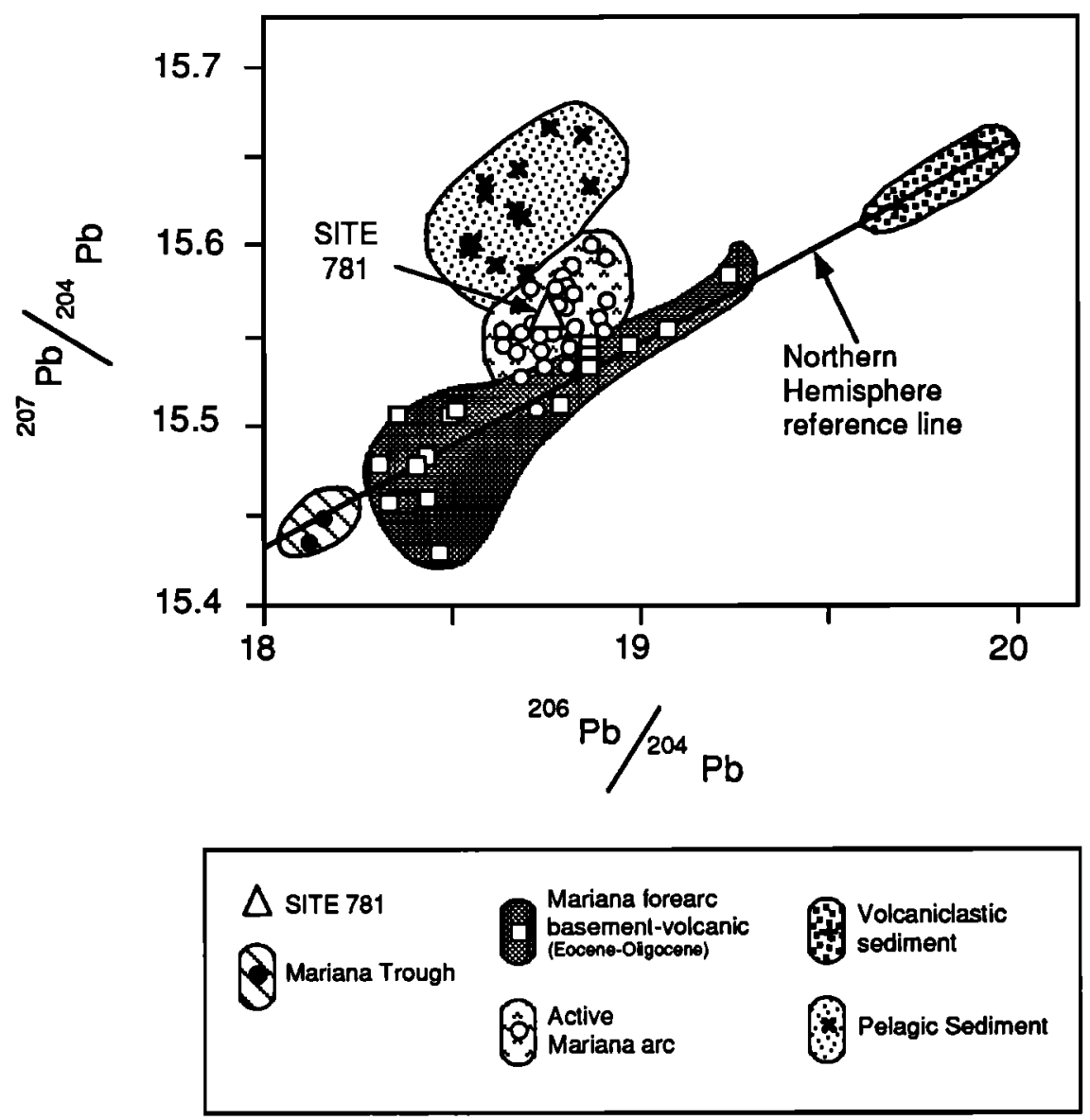

Fig. 11. Diagram of $\mathrm{Pb}$ isotope for the basalt sill at site 781, in comparison to Eocene-Oligocene forearc boninitic-tholeiitic lavas and lavas from the Mariana Trough and active Mariana arc.

younger arc to the west. The young age of the site 781 basalt (1.7 $\mathrm{Ma}$ ) precludes such a model.

Another model proposed for forming forearc volcanic rocks is shown in Figure $12 b$. The forearc magma source here is from mantle beneath fractured oceanic crust. The resulting magmas should be MORB-like from such a mantle source. The magmas from site 781 are not MORB-like but are tholeiitic and characteristic of an island arc source, not an oceanic mantle source.

Yet another model involves the generation of magma from a subarc source that is diverted either as a lateral sill or inclined dike that eventually reaches the middle of the forearc (Figures $12 c$ and 13). Site 781 is $100 \mathrm{~km}$ from the island arc and the sill or dike would have to travel at least this distance through cold crust and sediment to reach the middle of the forearc. However, lateral dikes are known to travel distances of hundreds or even thousands of kilometers in extensional marine environments [Greenough et al., 1988; Greenough and Hodych, 1990].

The simplest model for the emplacement of the basalt at site 781 involves a source vertically beneath the site (Figure $12 d$ ). Such a source would presumably involve the melting of oceanic crust and sediment and the mantle wedge above the subducting slab to generate a tholeiitic basalt with the chemistry described earlier (Figure 13). However, a vertical feeder system directly under the forearc would require magma production where the depth to the subducted Pacific plate is only about 20 or $30 \mathrm{~km}$ deep [Hussong and Uyeda, 1981; Eguchi, 1984]. This region of the subducted slab beneath the forearc is probably too shallow to have generated sufficient heat to melt the overlying mantle wedge, unless melting temperatures are lowered sufficiently by hydration of the region through extensional fracturing. If the magma source is directly beneath site 781 , then thermal models of this forearc will undoubtedly have to be revised to allow for shallow melting. Without deep-penetration seismic reflection data, we cannot confirm any particular model.

The 2000-m-high Conical Seamount is $13 \mathrm{~km}$ southeast of site 781 in the center of the forearc. Conical Seamount is composed in part of cold serpentine muds that have been extruded onto the sea floor, forming a small mountain some 20 $\mathrm{km}$ across. We find enigmatic the fact that this central part of the Mariana forearc has been the site of both cold serpentine extrusion at Conical Seamount and hot basaltic intrusion at site 781 during the late Cenozoic.

\section{Conclusions}

Seismic reflection surveys revealed a small horst and graben structure in the midregion of the Mariana forearc at $19^{\circ} 30 \mathrm{~N}$ and near Conical Seamount, a serpentine mud volcano. A highamplitude reflection occurs about 70 mbsf within the horst and can be seen on both sides of the fault bounding the graben. Drilling at site 781 intersected 13 to $25 \mathrm{~m}$ of reversely polarized, Pleistocene $(1.7 \mathrm{Ma})$ tholeiitic basalt sill in 


\section{Models For Forearc Volcanism At Site 781}

A. Subarc source when subducting slab is seaward of present location (tectonic erosion of forearc) basalt is too young

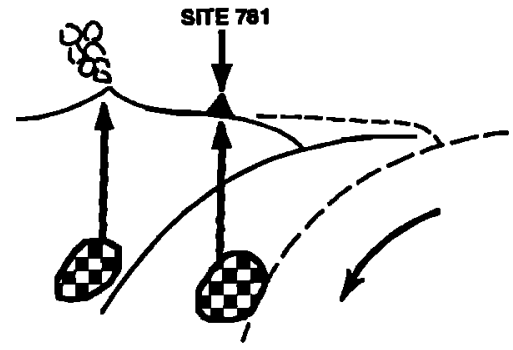

C. Subarc source and lateral sill injection into the forearc mechanically difficult but possible

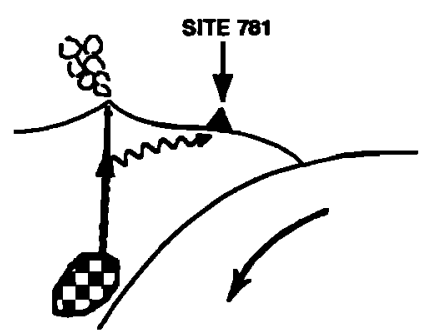

B. Source in fractured oceanic crust - basalt chemistry wrong

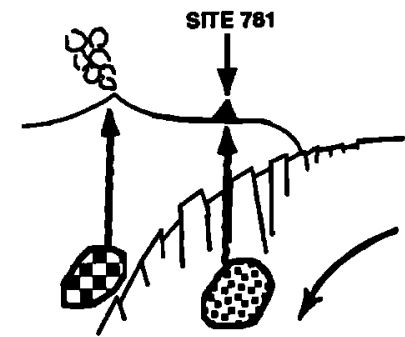

D. Simplest model vertical injection of magma from a source directly beneath Site 781 . thermally difficult

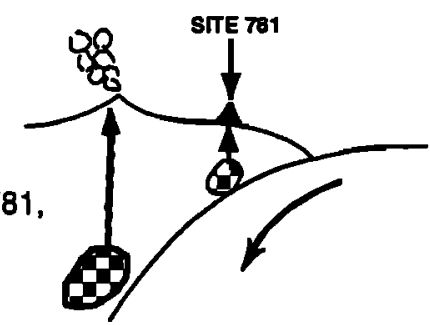

Fig. 12. Schematic diagram showing models for forearc volcanism. (a) A deep source (about $150-200 \mathrm{~km}$ or normal depths for island-arc volcanoes) during an earlier time period, when the subducting slab was located seaward of its present location, implying tectonic erosion of the forearc. The basalt at site 781 is too young for this model. (b) A magma source from within or below the fractured and subducting oceanic lithosphere. The chemistry of the site 781 basalt does not fit this model. (c) A mechanically difficult model of lateral magma transport along a conduit from near the magma sources for the active volcanoes. (d) Simplest model involving vertical injection of magma from a source beneath site 781. Diagram is adapted from Hussong and Uyeda [1981a].

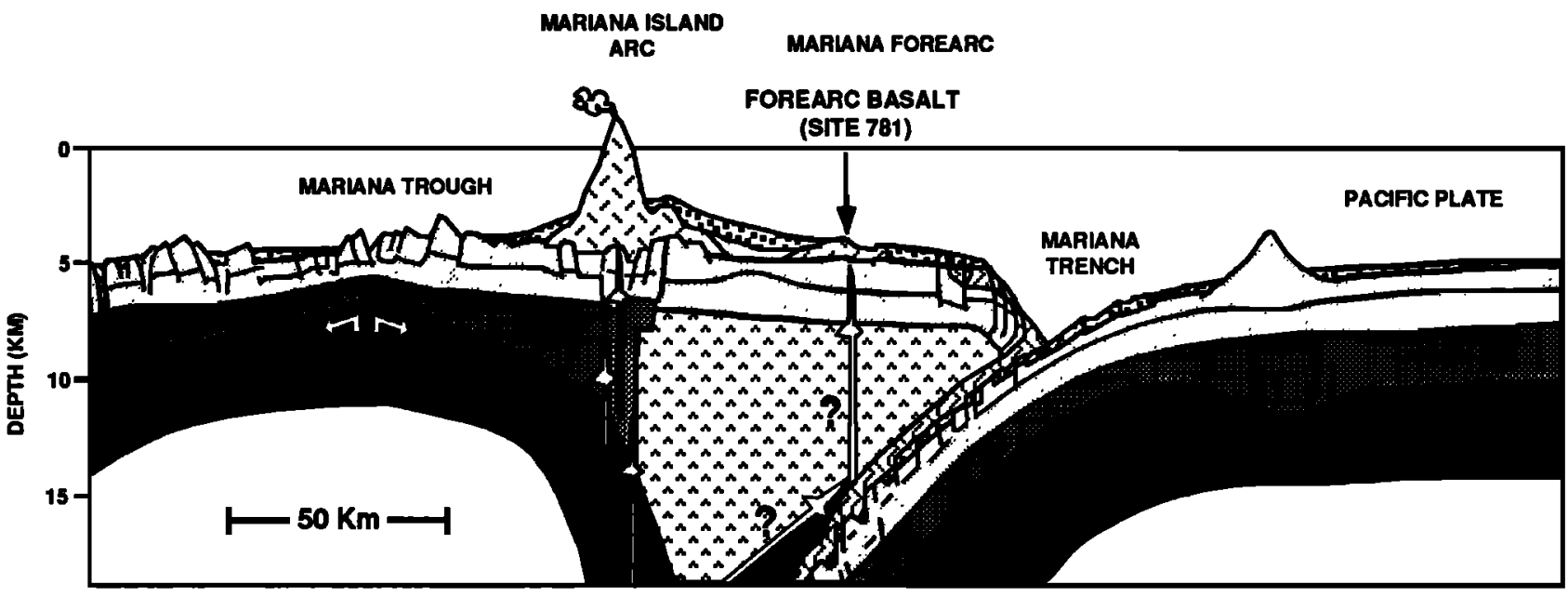

\section{EXPLANATION:}

\begin{tabular}{|c|c|c|c|c|}
\hline BP4: & Sediment & $\therefore \quad \therefore$ & $\begin{array}{l}\text { Upper volcanic crust - } \\
\text { Velocities of } 3.0 \text { to } 6.1 \mathrm{~km} / \mathrm{s}\end{array}$ & Manile (MORB) \\
\hline & $\begin{array}{l}\text { Deformed Sedlment - } \\
\text { Offscreped \& subducted }\end{array}$ & $n_{n}^{n}$ & $\begin{array}{l}\text { Older, rifted volcanlc } \\
\text { arc crust - velocities of } \\
6.1 \text { to } 7.2 \mathrm{~km} / \mathrm{s}\end{array}$ & Magma injectlon \\
\hline & $\begin{array}{l}\text { Contemporary volcanic } \\
\text { rocks - velocities of } 3.0 \text { to } \\
4.0 \mathrm{~km} / \mathrm{s}\end{array}$ & & $\begin{array}{l}\text { Lower crust - veloclties of } \\
6.5 \text { to } 7.9 \mathrm{~km} / \mathrm{s}\end{array}$ & \\
\hline
\end{tabular}

Fig. 13. Cross section of the Mariana arc system, with site 781 projected onto the crustal section. Crustal section adapted from Hussong and Uyeda [1981], based on their seismic refraction and reflection measurements. The basalt sill drilled at site 781 is derived from shallow(?) melting of the mantle wedge beneath site 781 and above the subducting slab or by lateral transport(?) from magma sources beneath the active island arc. 
normally polarized, late Pliocene (2.5 Ma) sediment. The basalt sill is chemically and petrographically homogeneous and appears to be a single cooling unit.

Geochemical analysis indicates that the basalt sill is an island-arc tholeiite (IAT) similar to lavas from the active Mariana arc volcanoes. Multielement analysis of the basalt indicates a magma source from the mantle above the subduction zone. Further drilling and seismic reflection surveys are necessary to delineate the magma conduits that fed the sill at site 781 and to determine whether these conduits extend from the forearc to the magma pools feeding the active island arc.

Acknowledgments. The authors thank Sherman H. Bloomer, Paul R. Carlson, Alan K. Cooper, T. H. Dixon, John D. Greenough, Randolph A. Koski, Mark K. Reagan, Robert J. Stern, and Tracy L. Vallier for their thoughtful and helpful reviews of this manuscript. LEJ thanks D. Sims and J. Glasser for XRF analyses and thin section preparation, respectively, on board the D/V JOIDES Resolution; T. Husslebosch for assisting with XRF and microprobe analyses at the University of Hawaii; and G. Eberhardt and C. Langmuir for assistance during REE analyses at Lamont-Doherty Geological Observatory. This research is part of the LEJ's doctoral dissertation at the University of Hawaii. LEJ acknowledges USSAC for salary support during leg 125 and for a post cruise grant (TAMU Research Foundation P.O. 20265 and 20352). JAP thanks Sorena Sorensen for her help in obtaining Mariana arc samples from the Smithsonian collection, Matthew Thirlwall and Gerry Ingram (RHBNC, London) for isotope facilities, and the Natural Environment Research Council (England) for a research grant (GST/02/416).

\section{REFERENCES}

Bloomer, S. H., R. J. Stem, E. Fisk, and C. H. Geshwind. Shoshonitic volcanism in the northem Mariana Arc, 1, Mineralogic and major and trace element characteristics, J. Geophys. Res., 94, 4469-4496, 1989.

Cox, A., and G. B. Dalrymple. Statistical analysis of geomagnetic reversal data and precision of potassium-argon dating, $J$. Geophys. Res., 72, 2603-2614, 1967.

Dixon, T. H., and R. Batiza. Petrology and chemistry of recent lavas in the northern Marianas: Implications for the origin of island arc basalts, Contrib. Mineral. Petrol., 70, 167-181, 1979.

Eguchi, T. Seismotectonics around the Mariana Trough, Tectonophysics, 102, 33-52, 1984.

Fryer, P., and D. M. Hussong. SeaMARC II studies of subducting seamounts, in Formation of Active Ocean Margins, edited by N. Nasu, pp. 291-306, Terra Scientific, Tokyo, 1985.

Fryer, P., J. A. Pearce, L. B. Stokking, et al. Proc. Ocean Drilling Program Initial Rep., 125, 1990.

Fryer, P., J. A. Pearce, L. B. Stokking, et al. Proc. Ocean Drilling Program, Initial Rep., 125, 1992.

Gill, J. B., Orogenic Andesites and Plate Tectonic, 390 pp., Springer Verlag, New York, 1981.

Greenough, J. D. Minor phases in the earth's mantle: evidence from trace- and minor-element patterns in primitive alkaline magmas. Chem. Geol., 69, 177-192, 1988.

Greenough, J. D., and J. P Hodych. Evidence for lateral magma injection in the Early Mesozoic dykes of eastem North America, in Mafic Dykes and Emplacement Mechanisms, edited by A. J. Parker, C.P. Rickwood, and D. H. Tucker, pp. 35-46, A. A. Balkema, Rotterdam, 1990.

Greenough, J. D., A. Ruffman, and J. V. Owen. Magma injection directions inferred from a fabric study of the Popes Harbour dike, eastern shore, Nova Scotia, Canada, Geology, 16, 547-550, 1988.

Hart, S. R. A large-scale isotope anomaly in the southem hemisphere mantle, Nature, 300, 753-757, 1984.

Hawkesworh, C. J., R. K. O'nions, R. J. Pankhurst, P. J. Hamilton, and N. M. Evensen. A geochemical study of island-arc and back-arc tholeiites from the Scotia Sea, Earth Planet. Sci. Lett., 36, 253-262, 1977.

Hickey, R. L., and F. A. Frey. Geochemical characteristics of boninite series volcanics: implications for their source, Geochim. Cosmochim. Acta, 46, 2099-2115, 1982.

Hickey-Vargas, R. Boninites and tholeiites from DSDP site 458,
Mariana forearc, in Boninites and Related Rocks, edited by A. J. Crawford, pp. 339-356, Unwin Hyman, London, 1989.

Hickey-Vargas, $\mathbf{R}$. and M. K. Reagan. Temporal variation of isotope and rare-earth element abundances in volcanic rocks from Guam: Implications for the evolution of the Mariana arc, Contrib. Mineral. Petrol., 97, 497-508, 1987.

Hilde, T. W. C., S. Uyeda, and L. Kroenke. Evolution of the westem Pacific and its margin, Tectonophysics, 38, 145-165, 1977,

Hussong, D. M., and P. Fryer. Structure and tectonics of the Mariana arc and fore-arc: Drillsite selection surveys, Initial Rep., Deep Sea Drill. Proj., 60, 33-44, 1981.

Hussong, D. M., and S. Uyeda. Tectonic processes and the history of the Mariana Arc: A synthesis of the results of Deep Sea Drilling Project leg 60, Initial Rep. Deep Sea Drill. Proj., 60: 909-929, 1981. Irvine, T. N, and W. R. Baragar. A guide to the chemical classification of the common igneous rocks, Can. J. Earth Sci., 8, 523-545, 1971.

Karig, D. E. Structural history of the Mariana Island Arc system, Geol. Soc. Am. Bull., 82, 323-344, 1971.

Karig, D. E. Basin genesis in the Philippine Sea, Initial Rep. Deep Sea Drill. Proj., 31, 857-879, 1975.

Kobayashi, K. Cycles of subduction and Cenozoic arc activity in the northwestern Pacific margin, in Geodynamics of the Western PacificIndonesian Region, Geodyn. Ser., vol 11, edited by T. W. C. Hilde and S. Uyeda, pp. 287-301, AGU, Washington, D.C., 1983a.

Kobayashi, K. Fore-arc volcanism and cycles of subduction, in Arc Volcanism: Physics and Tectonics, edited by D. Shimozuru and I. Yokoyama, pp. 153-163, Terra Scientific, Tokyo, 1983b.

Lin, P.-N., R. J. Stern, and S. H. Bloomer. Shoshonitic volcanism in the northem Mariana arc, 2, Large-ion lithophile and rare earth element abundances: Evidence for the source of incompatible element enrichments in intraoceanic arcs, J. Geophys. Res., 94, 4497-4514, 1989.

Marlow, M. S., N. F. Exon, and D. L. Tiffin. Widespread lava flows and sediment deformation in a forearc setting north of Manus Island Northem Papua New Guinea in Geology and Offshore Resources of Pacific Island Arcs-New Ireland and Manus Region, Papua New Guinea, Earth Sci. Ser., vol. 9, edited by M. S. Marlow, S. V. Dadisman, and N. F. Exon, pp. 221-237, Circum-Pacific Council for Energy and Mineral Resources, 1988.

Marlow, M. S., D. L. Merrill, and Shipboard Scientific Party, Part 3: Underway geophysics, Proc. Ocean Drill. Program Initial Rep., 125, 41-67, 1990.

Mattey, D. P., N. G. Marsh, and J. Tamey. The geochemistry, mineralogy and petrology of basalts from the West Philippine and Parece Vela Basins and from the Palau-Kyushu and West Mariana Ridges, Deep Sea Drill. Project Leg 59, Initial Rep. Deep Sea Drill. Proj., 59, 753-797, 1980.

Meijer, $\mathrm{A} . \mathrm{Pb}$ and $\mathrm{Sr}$ isotopic data bearing on the origin of volcanic rocks from the Mariana island-arc system, Geol. Soc. Am. Bull., 87, 1358-1369, 1976.

Meijer, A. Primitive arc volcanism and a boninite series: examples from westem Pacific island arcs, in The Tectonic and Geologic Evolution of Southeast Asian Seas and Islands, edited by D. E. Hayes, pp. 269-282, AGU, Washington D.C., 1980.

Meijer, A. The origin of low-K rhyolites from the Mariana frontal arc, Contrib. Mineral. Petrol., 83, 45-51, 1983.

Mrozowski, C. L., D. E. Hayes, and B. Taylor. Multichannel seismic reflection surveys of leg 60 sites, Initial Rep. Deep Sea Drill. Proj. $60,57-70,1981$

Norrish, K., and B. Chappell. X-ray fluorescence spectrometry, in Physical Methods in Determinative Mineralogy, edited by X. Zussman, pp. 201-272, Academic, San Diego, Calif., 1977.

Norrish, K., and J. T. Hutton. An accurate $X$-ray spectrographic method for the analysis of a wide range of geological samples, Geochim. Cosmochim. Acta, 33, 31-453, 1969.

Ogawa, Y., and J. Naka. Emplacement of ophiolitic rocks in forearc areas: Examples from central Japan and Izu-Mariana-Yap island arc system, in Ophiolites and Ocean Lithosphere, vol. 13, edited by I. G. Gass, S. J. Lippard, and A. W. Shelton, et al., pp. 291-302, Blackwell Scientific, Boston, Mass, 1984.

Okada, H., and D. Bukry. Supplementary modification and introduction of code numbers to the low-latitude coccolith biostratigraphic zonation, Mar. Micropaleontol., S(3), 321-325, 1980.

Pearce, J. A. Role of the sub-continental lithosphere in magma genesis at active continental margins, in Continental Basalts and Mantle Xenoliths, edited by D. J. Hawkesworth and M. J. Norry, Pp. 231249. Shiva, London 1983. 
Peccerillo, A., and S. R. Taylor. Geochemistry of Eocene calc-alkaline rocks from the Kastamonu area, Northem Turkey, Contrib. Mineral Petrol., 58, 63-81, 1976.

Stem, R. J., S. H. Bloomer, L. Ping-Nan, and N. C. Smoot. Submarine arc volcanism in the southern Mariana arc as an ophiolite analogue, Tectonophysics, 168, 151-170, 1989.

Sun, S. S., and W. F. McDonough. Chemical and isotopic systematics of oceanic basalts: implications for mantle composition and processes, Magmatism in the Ocean Basins, Spec. Pap. Geol. Soc. London, 42, 313-345, 1989.

Taylor, J. R. An Introduction to Error Analysis, 270 pp. University Science Books, Mill Valley, Calif., 1982.

Uyeda, S., and Z. Ben-Avraham. Origin and development of the Philippine Sea, Noture Phys. Sci., 240, 176-178, 1972.

Venturelli, G., R. S. Thorpe, G. V. Dal Piaz, A. Del Moro, and P. J. Potts. Petrogenesis of calc-alkaline, shoshonitic and associated ultrapotassic Oligocene volcanic rocks from the Northwestem Alps, Italy, Contrib. Mineral. Petrol., 86, 209-220, 1984.

Volpe, A. M., J. D. McDougall and J. W. Hawkins. Mariana Trough basalts (MTB): trace element and Sr-Nd evidence for mixing between MORB-like and arc-like melts, Earth Planet. Sci. Lett., 82, 241-254, 1987.

Wood, D. A., N. G. Marsh, J. Tamey, L. J. Joron, P. Fryer, and M.
Treuil. Geochemistry of igneous rocks recovered from a transect across the Mariana Trough, Arc, Fore-Arc, and Trench, sites 453 through 461, Deep Sea Drilling Project Leg 60, Initial Rep. Deep Sea Drill. Proj., 60, 611-645, 1981.

Woodhead, J. D. The origin of geochemical variations in Mariana lavas: A general model for petrogenesis of intraoceanic island arcs, $J$. Petrol., 29, 805-830, 1988.

Woodhead, J. D. Geochemistry of the Mariana arc (Western Pacific): source composition and processes, Chem. Geol., 76, 1-24, 1989.

P. B. Fryer and L. E. Johnson, University of Hawaii, 2525 Correa Road, Honolulu, HI 96822.

M. S. Marlow and L. B. G. Pickthom, U.S. Geological Survey, 345 Middlefield Road, Menlo Park, CA 94025-3591.

B. J. Murton. Institute of Oceanographic Sciences, Wormley, Surrey GU8 SUB, England.

J. A. Pearce, Department of Geological Sciences, Durham Univerșity, South Road, Durham DH1 3LE, England.

(Received October 4, 1991; revised March 3, 1992; accepted May 7, 1992.) 